\title{
United States: Publication of Financial Sector Assessment Program Documentation- Technical Note on Regulatory Reform: OTC Derivatives
}

This paper was prepared based on the information available at the time it was completed on July 23, 2010. The views expressed in this document are those of the staff team and do not necessarily reflect the views of the government of the United States or the Executive Board of the IMF.

The policy of publication of staff reports and other documents by the IMF allows for the deletion of market-sensitive information.

Copies of this report are available to the public from

International Monetary Fund • Publication Services

700 19th Street, N.W. • Washington, D.C. 20431

Telephone: (202) 623-7430 • Telefax: (202) 623-7201

E-mail: publications@imf.org • Internet: http://www.imf.org

\section{International Monetary Fund Washington, D.C.}




\section{FinANCIAL SECtor ASSESSMENT PROGRAM}

\section{UNITED STATES OF AMERICA}

\section{REGULATORY REFORM: OTC DERIVATIVES MARKETS \\ TECHNICAL NOTE}

JULY 2010 



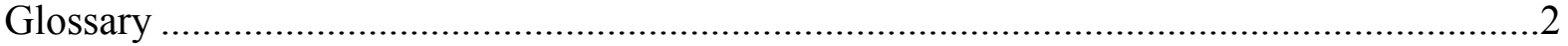

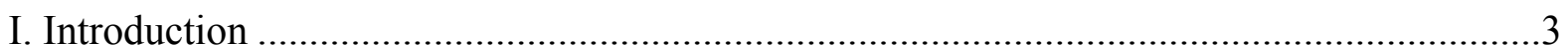

II. Problem Areas Revealed by the Financial Crisis ............................................................

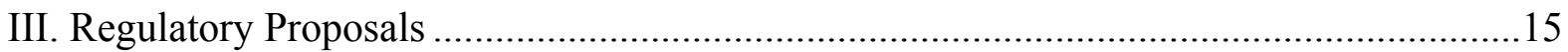

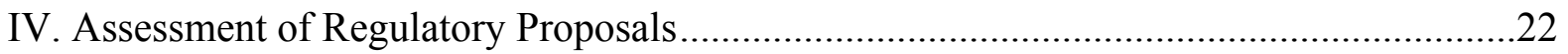

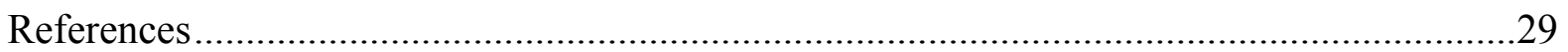

Tables

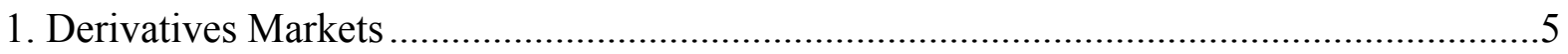

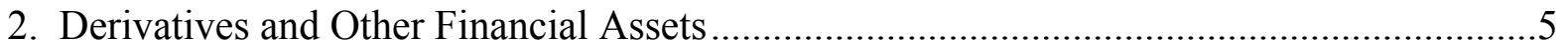

3. Credit Exposure on Detivatives Prior to Netting .............................................................6

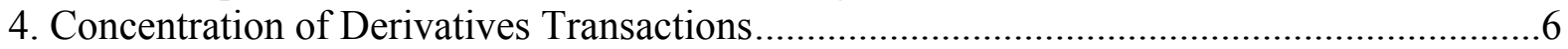

5. Total Credit Exposure to Risk Based Capital .....................................................................

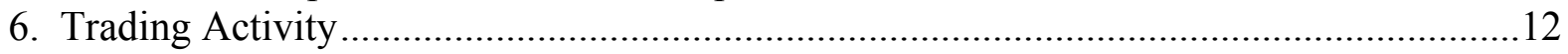

Figures

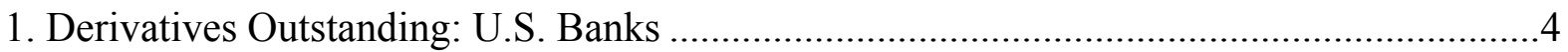

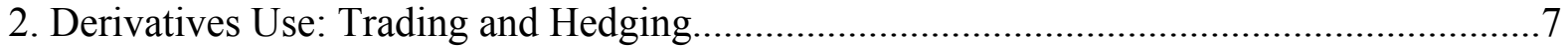

3. Trading Volume in Credit Derivatives Markets ……….................................................12

4. Liquidity in OTC Derivatives Markets: Bid/Ask Spreads in CDS ......................................13

Appendix

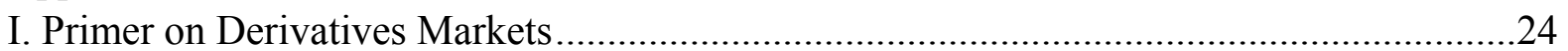




\section{GLOSSARY}

AAA

AIG

BIS

CPSS

$\mathrm{CCP}$

CDS

CFTC

$\mathrm{CH}$

CFMA

CSA

DCO

DTCC

ICAP

ICE

IRS

ISDA

KIKOs

MSP

MTA

OTC

SEC

SEF

TARNs
Highest credit rating at $\mathrm{S} \& \mathrm{P}$ and Fitch rating agencies

American International Group (insurance company)

Bank for International Settlements

Basel Committee on Payments and Settlement Systems

Central Counterparty

Credit Default Swap

Commodity Futures Trading Commission

Clearing House

Commodity Futures Modernization Act of 2000

Credit Support Annex

Derivatives Clearing Organization

Depository Trust and Clearing Corporation

An inter-dealer broker in securities and derivatives

Intercontinental Exchange (a derivatives exchange and clearing house)

Interest Rate Swap

International Swaps and Derivatives Association

Knock-in knock-out options

Major Swap Participant

Master Trading Agreement

Over-the-Counter

Securities and Exchange Commission

Swap Execution Facilities

Target Redemption Notes 


\section{INTRODUCTION ${ }^{1}$}

1. OTC derivatives markets were an increasing source of vulnerability heading into the crisis. This vulnerability reflected their degree of leverage, low prudential standards, and lack of transparency. The market lacked designated market makers and frequent and thorough reporting requirements, and trading was conducted bilaterally or, if brokered, only in the interdealer market. Inadequate use of collateral and heavy concentration of trading in a few dealers further weakened the market structure.

\section{To be sure, some areas of this vulnerability were a concern ahead of the crisis} and recent efforts had succeeded in improving the operational infrastructure. Major derivatives dealers and the OTC Derivatives Supervisors Group had begun efforts to strengthen the market infrastructure for credit derivatives. These included a reduction in the backlog of trade confirmations; increased automation of trade processing; establishment of the novation protocol; increased usage of auction based settlement mechanism for cash settlement of credit events; and establishment of a central repository for CDS trade data and central payment settlement through CLS. These steps likely helped OTC derivatives market to operate during the financial crisis more smoothly than otherwise. Trade confirmations outstanding for Credit Default Swap (CDS) also fell as a result of work undertaken by the OTC Derivatives Supervisors Group and the broker/dealer community. ${ }^{2}$

3. Nonetheless, OTC derivatives markets contributed to the financial crisis. Credit derivatives facilitated the development and growth of the structured securities markets and the purchasing, packaging and distribution of several trillions of dollars of poorly underwritten loans and mortgages. ${ }^{3}$ As the crisis broke, parts of the OTC derivatives market (especially for credit derivatives) suffered significant dislocations and disfunctionality that left trading volumes lower, bid-ask quotes wider, trading lot sizes smaller, and price discovery impaired. Inconsistent collateral requirements helped exacerbate counterparty risk aversion and contributed to a destabilizing rush to collateralize exposures after financial markets were already stressed.

\footnotetext{
${ }^{1}$ The primary author is Randall Dodd.

${ }^{2}$ Since the crisis, additional improvements have been made in the areas of portfolio reconciliation and trade compression efforts. For example, all major dealers now reconcile derivative positions daily using an automated data platform, and dealers and some end-users are currently participating in a pilot program to fine tune a new International Swaps and Derivatives Association (ISDA) dispute resolution protocol.

${ }^{3}$ The BCBS's Joint Forum on Credit Risk Transfer stated "Market participants have come to view the credit derivative indexes as a key source of pricing information on these markets. The liquidity and price transparency that indexes provide has enabled credit risk to become a traded asset class." April 2008.
} 
4. The regulatory reforms proposals, first advanced by the Administration and subsequently passed by Congress, aim at addressing these concerns. ${ }^{4}$ The reforms of OTC derivatives markets introduce registration and reporting requirements, raise prudential standards, promote exchange trading and central clearing, improve transparency, and broaden enforcement actions against market misconduct. The reforms include collateral requirements for OTC derivatives (with exemptions for certain end-users) and higher capital requirements for dealers. They will move more of the market onto exchanges (or so-called swap execution facilities) and clear more of the transactions through derivatives clearing organizations (i.e., clearing houses). The regulatory reforms also enhance regulators' enforcement authority, and create additional investor protections to the OTC derivatives marketplace.

\section{Problem Areas Revealed by the Financial Crisis}

\section{In the two decades prior to the crisis, derivatives markets, and especially for} OTC derivatives, grew rapidly to constitute a major component of the U.S. financial system (Figure 1). A six-fold expansion in notional amounts outstanding between 1998 and 2009 was accompanied by a widening array of products and instruments, including OTC derivatives products linked to interest rates, foreign exchange, equities, commodities and credit derivatives (Table 1). Table 2 presents figures for the total notional amounts outstanding and for gross positive fair value. These figures are comparable in magnitude to other sections of the U.S. financial system (of course notional amounts and fair value of derivatives outstanding are not the same metric as the market value of principal used to measure other sectors of the financial market, but they are the only readily available measures and are used here for illustrative purposes).

Figure 1. Derivatives Outstanding: U.S. Banks

(US\$ trillion)

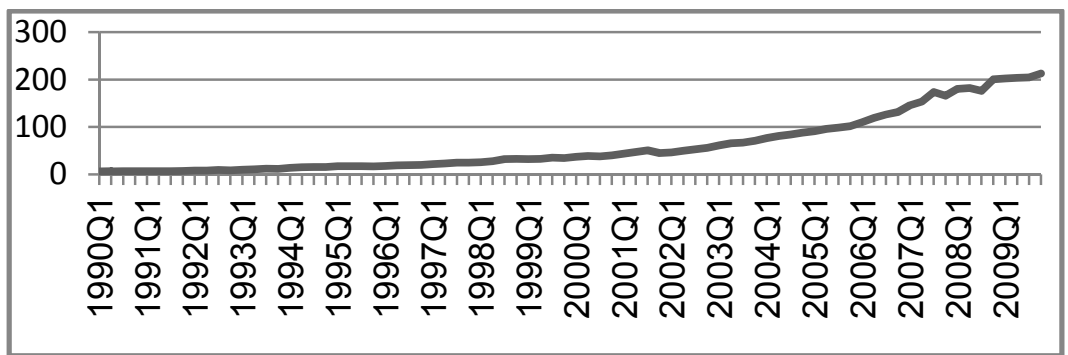

Source: OCC Fact Sheet.

\footnotetext{
${ }^{4}$ H.R. 4173, Restoring American Financial Stability Act of 2010, and the related Conference Report were passed by the House of Representatives and the Senate.
} 


\section{Table 1. Derivatives Markets}

(Notional Outstanding, US\$ billion)

\begin{tabular}{|c|c|c|c|c|c|c|c|c|c|c|c|c|}
\hline & 1998 & 1999 & 2000 & 2001 & 2002 & 2003 & 2004 & 2005 & 2006 & 2007 & 2008 & 2009 \\
\hline Interest rate & 24,785 & 27,772 & 32,938 & 38,305 & 48,347 & 61,856 & 75,518 & 84,520 & 107,415 & 129,574 & 164,404 & 179,555 \\
\hline Foreign exchange & 7,386 & 5,915 & 6,099 & 5,736 & 6,076 & 7,182 & 8,607 & 9,282 & 11,900 & 16,614 & 16,824 & 16,553 \\
\hline Equities & 501 & 672 & 858 & 770 & 783 & 829 & 1,120 & 1,255 & 2,271 & 2,522 & 2,207 & 1,685 \\
\hline Commodities & 183 & 171 & 222 & 179 & 233 & 214 & 289 & 598 & 893 & 1,073 & 1,050 & 979 \\
\hline Credit derivatives & 144 & 287 & 426 & 395 & 635 & 1,001 & 2,347 & 5,822 & 9,019 & 15,861 & 15,897 & 14,036 \\
\hline TOTAL & 32,999 & 34,816 & 40,543 & 45,385 & 56,075 & 71,082 & 87,880 & 101,477 & 131,499 & 165,645 & 200,382 & 212,808 \\
\hline Growth rate, annual & & $5.5 \%$ & $16.4 \%$ & $11.9 \%$ & $23.6 \%$ & $26.8 \%$ & $23.6 \%$ & $15.5 \%$ & $29.6 \%$ & $26.0 \%$ & $21.0 \%$ & $6.2 \%$ \\
\hline
\end{tabular}

Table 2. Derivatives and Other Financial Assets

(US\$ billions)

\begin{tabular}{lrrrrrrrrrrr}
\hline & 2003 & 2004 & 2005 & 2006 & 2007 & 2008: I & 2008: II & 2008: III & 2008: IV & 2009: I & 2009: II \\
\hline Non-financial business debt & 7,336 & 7,800 & 8,480 & 9,366 & 10,633 & 10,832 & 11,034 & 11,140 & 11,200 & 11,204 & 11,178 \\
Financial sector debt & 10,925 & 11,920 & 12,984 & 14,272 & 16,192 & 16,408 & 16,667 & 16,944 & 17,084 & 17,014 & 16,521 \\
Household debt & 8,974 & 10,039 & 11,175 & 12,248 & 13,037 & 13,078 & 13,100 & 13,092 & 13,023 & 12,948 & 12,877 \\
Equities (market cup.) & 16,451 & 18,947 & 20,643 & 24,334 & 25,565 & 23,290 & 22,777 & 20,142 & 15,780 & 13,926 & 16,932 \\
$\quad$ Total & 43,686 & 48,706 & 53,282 & 60,219 & 65,427 & 63,608 & 63,577 & 61,318 & 57,086 & 55,093 & 57,509 \\
Derivatives - notional & 71,100 & 87,900 & 101,500 & 131,500 & 165,600 & 180,300 & 182,100 & 175,800 & 200,400 & 202,000 & 203,500 \\
$\quad$ Gross fair values & 1,173 & 8,242 & 8,763 & 9,782 & 1,902 & 3,237 & 2,753 & 2,772 & 7,100 & 6,325 & 4,641 \\
\hline
\end{tabular}

Source: OCC Fact Sheet and Federal Reserve Z Survey.

6. The growth in OTC derivatives was accompanied by an increase in counterparty credit risk. In particular, credit exposure from the gross fair value of outstanding amounts of OTC derivatives contracts grew steadily from 2002 until the beginning of the crisis, reaching US\$7.1 trillion at year-end 2008 and remaining as high as US\$4.1 trillion at the end of 2009 (Table 3 ). Both gross and net values show the impact of price volatility on credit exposures from derivatives. 
Table 3. Current Credit Exposure on Derivatives Gross Fair Value Prior to Netting and After Netting ${ }^{5}$

(US\$ billions)

\begin{tabular}{lll}
\hline 2009 & 4,053 & 398 \\
2008 & 7,100 & 800 \\
2007 & 1,902 & 309 \\
2006 & 1,132 & 185 \\
2005 & 1,235 & 191 \\
2004 & 1,328 & 220 \\
2003 & 1,173 & 217 \\
2002 & 1,171 & 219 \\
\hline Source: OCC Fact.
\end{tabular}

\section{The growth has been concentrated in a few firms and in their trading books} (Table 4 and Figure 2). ${ }^{6}$ Almost 97 percent of outstanding notional amounts are concentrated in 5 banks. ${ }^{7}$ The total credit exposure to these banks, measured by current exposure plus potential future exposure, represents a large total exposure relative to their regulatory capital ${ }^{8}$ (Table 5).

Table 4. Concentration of Derivatives Transactions

\begin{tabular}{|c|c|c|c|c|c|c|}
\hline & \multicolumn{2}{|c|}{ Top 5 Banks } & \multicolumn{2}{|c|}{ Other Banks } & \multicolumn{2}{|c|}{ All Banks } \\
\hline & US\$ bn & Percent & US\$ bn & Percent & US\$ bn & Percent \\
\hline Futures \& forwards & 22,670 & 11.1 & 2,034 & 1.0 & 24,704 & 12.1 \\
\hline Swaps & 132,513 & 65.1 & 3,090 & 1.5 & 135,602 & 66.6 \\
\hline Options & 28,809 & 14.2 & 904 & 0.4 & 29,714 & 14.6 \\
\hline Credit derivatives & 12,546 & 6.2 & 894 & 0.4 & 13,440 & 6.6 \\
\hline Total & 196,538 & 96.6 & 6,922 & 3.4 & 203,460 & 100.0 \\
\hline
\end{tabular}

Source: Data from OCC from Call Reports.

\footnotetext{
${ }^{5}$ The left column is gross fair value and the right column is the net current credit exposure (NCCE) measured at the end of calendar year.

${ }^{6}$ These figures now include former broker-dealers Goldman Sachs and Morgan Stanley which have reorganized themselves into bank holding companies. A historical chart would show similar degrees of concentration dating back for more than a decade.

${ }^{7}$ The banks that comprise the top banks have changed over the years due to mergers and the recent rechartering of major broker-dealers like Goldman Sachs and Morgan-Stanley.

${ }^{8}$ Notional amounts outstanding denotes the general level of activity or size of the market, but is not an accurate measure of risk.
} 
Figure 2. Derivatives Use: Trading and Hedging at U.S. Banks (US\$ billion and percent of notional outstanding)

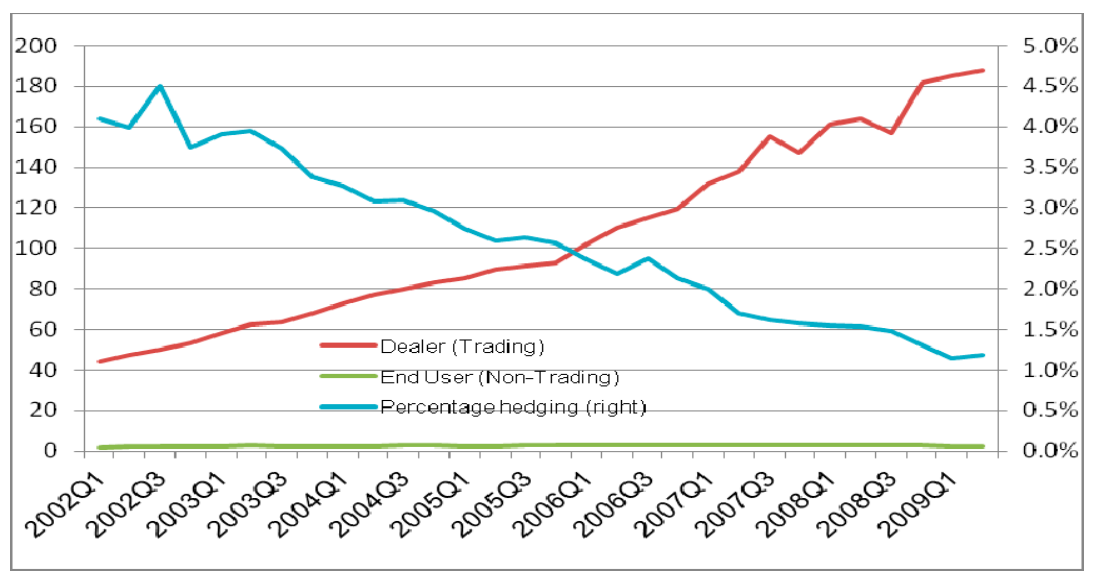

Source: OCC Fact Sheet.

Table 5. Total Credit Exposure to Risk Based Capital (In Percent)

\begin{tabular}{lrrrrrrrrrr}
\hline & 2001 & 2002 & 2003 & 2004 & 2005 & 2006 & 2007 & 2008 & $2009: I$ & $2009:$ IV \\
\hline JPMorgan Chase & 439 & 427 & 548 & 361 & 315 & 347 & 419 & 382 & 323 & 265 \\
Goldman Sachs & & & & & & & & 1,024 & 1,048 & 766 \\
Bank of America & 95 & 114 & 119 & 143 & 97 & 93 & 115 & 179 & 169 & 151 \\
Citibank & 123 & 147 & 198 & 221 & 267 & 268 & 223 & 278 & 213 & 180 \\
Wells Fargo & & & & & & & & & & 60 \\
Top 5 Banks & 175 & 180 & 243 & 228 & 205 & 220 & 239 & 330 & 286 & 284 \\
\hline
\end{tabular}

Source: OCC Fact Sheet.

\section{Transparency}

8. The level of transparency, in regards to market prices, in the OTC market is less than in exchange-traded markets. OTC markets are generally built around interdealer markets in which dealers trade with one another - often facilitated by interdealer brokers or electronic brokering screens. Clients and end-users generally are not privy to the prices at which these trades occur and are dependent upon quotes made by the dealer with whom they have established trading relationships. The difference in prices is one of the low risk ways that dealers profit from trading.

9. There is a lack of information on the amount, maturity, and concentration of outstanding OTC derivatives positions. This reflects the general absence of reporting requirements regarding price, volume, open interest, and large trader positions. The lack of 
transparency means that participants are unable to reliably mark some exposures to the market. By contrast, exchange-traded derivatives markets regularly provide information not only about prices but also trading volume and open interest, as well as the extent to which different categories of traders are long and short. There are also reporting requirements to the supervisory authorities that mean that large, concentrated positions in the futures market are being monitored daily and reported weekly — although in aggregated amounts - to the public market. Of course the opacity of OTC markets, to some extent, reflects the customization of the instruments involved, which means that information on prices and quantities would not be as useful without further information about contract details.

\section{Nonetheless, some pre-trade data are available on the OTC derivatives market.}

Interdealer brokers and Bloomberg and Markitwire systems provide information on quotes and execution prices on a variety of maturities of single-currency interest rate swaps, options as well as credit derivatives. Similarly, ICAP — the largest interdealer broker in OTC securities and derivatives markets, in its White Paper (ICAP 2009) estimates that "about 80 percent of all trading in credit default swap indices and 50 percent of all trading in credit default swap single-name derivatives in Europe is conducted electronically." The fact that some contracts can be quoted and executed through multilateral electronic or voice brokerage systems suggests that they are to a large extent standardized. ${ }^{9}$ Credit derivative indices are already highly standardized with regard to dates, referenced entities, common definitions of credit events, and the recent transition to fixed coupon CDS is likely to reinforce this trend.

\section{Leverage and risk taking}

11. Derivatives transactions are inherently leveraged. Leverage is employed in the use of derivatives because it reduces the associated capital cost. However, the capital savings from leverage also encourages greater risk taking for a given amount of invested capital, potentially generating negative effects from such risk taking, if collateral is inadequate.

\section{The crisis revealed several negative effects and externalities from such risk}

taking. The leverage associated with OTC derivatives can quickly generate a large amount of counterparty credit risk. Sharp and sizable movement in market prices results in very large gains to one side of the transaction and puts greater stress on the other side of the transaction that experiences equally large losses. This increase in risk is exacerbated when collateral is insufficient or absent. A prominent example were the problems encountered by American International Group (AIG) Financial Products' failure, the arm of the company that was not regulated by the insurer regulators, where its uncollateralized credit derivatives positions

\footnotetext{
${ }^{9}$ A recent article in the Bank for International Settlement (BIS) Quarterly Review (Cecchetti, et al, 2009)) stated that "in order to facilitate transactions, derivatives contracts have in many cases become more standardized ....interest rate swaps and foreign exchange derivatives have become highly standardized through voluntary industry initiatives."
} 
enabled it to amass an enormous long credit exposure that generated massive mark-to-market losses. When AIG's credit rating was downgraded it required government support in order to meet margin calls and maintain solvency.

\section{Counterparty risk}

\section{Counterparty risk arises from the uncertainty regarding whether the other} party to the derivatives transaction will fully perform on the contract. While derivatives can serve as an effective financial instrument for the purposes of reducing risk or transferring it to a more willing or able counterparty, the trading of OTC derivatives entails counterparty risk, since it exposes each side of the transaction to the potential failure by the other party to adhere to the contract. When counterparty risk becomes heightened, market activity can become impaired by trading volume reductions and increasing bid-ask spreads. In such circumstances counterparty risk becomes so acute that market prices begin to reflect not only the underlying referenced item (e.g., interest rate risk), but also the riskiness of the counterparty in performing on the contract.

14. There are various means of mitigating or "managing" counterparty risk. One is to conduct a credit evaluation of the counterparty in order to determine its ability to pay or fulfill the terms of the derivative over the life of the contract. A thorough credit assessment can allow a derivatives trader to manage counterparty risk to some degree, where the trader limits trading to entities with highly-rated credit and limits the amount of exposure to each counterparty. Relying solely on the creditworthiness of counterparties to manage counterparty risk is sometimes referred to as "trading on capital."

\section{In contrast to "trading on capital," a more effective means of mitigating} counterparty risk is the use of margin or collateral. ${ }^{10}$ Counterparties can post margin as a performance bond against their full performance on the contract. In practice, the standards for use of collateral vary greatly. On derivatives exchanges, where multilateral clearing houses have existed for decades, ${ }^{11}$ market participants are required to post initial margin on new net positions in the market and then afterwards meet sometimes slightly lower maintenance margin requirements. In addition, the margin is adjusted each day according to changes in the market value of the position. If a position loses value, then the trader must post additional funds in what is known as variation margin payments - to assure that the maintenance margin requirement is satisfied.

\footnotetext{
${ }^{10}$ While economically the two are similar, semantically they differ in that the term margin is usually used to refer to the performance bond required for exchange-traded futures and options while collateral is used in the context of OTC derivatives transactions.

${ }^{11}$ Here the term clearing house is used to refer an entity providing the following post-trade services: trade confirmation, netting, novation of contracts with a central counterparty (usually with an AAA credit rating), and settlement.
} 
16. The industry practice for the use of collateral in OTC derivatives markets is different than that for exchange-traded derivatives. Counterparties often trade without requiring initial or maintenance collateral as a condition for the transaction. Instead they trade against capital, at least up to a threshold and then require the posting of variation margin or collateral once the exposure from losing derivatives positions exceeds the threshold. ${ }^{12}$ The amount of collateral and the types of allowable collateral vary from one counterparty to another. The terms of the collateral agreement are negotiated and then formalized through the Credit Support Annex (CSA) of the master trading agreement signed by the counterparties. ${ }^{13}$ The industry standard changed during the crisis to require greater collateralization.

17. There are no minimum collateral requirements in the OTC derivatives markets. The two counterparties can agree on a very low rate or a high rate and competition tends to put downward pressure on collateral requirements. Cash collateral absorbs a firm's liquidity and there is an opportunity cost to using relatively low yielding, high credit rated liquid securities such as Treasury bills. If a firm must borrow against illiquid assets or use Treasury securities as collateral, then the firm pays the credit spread between its borrowing cost and the return on Treasuries or cash. The direct competitive pressure to economize on these costs by pushing down collateral requirements is in contrast to investors' interest in seeing that the firm is adequately managing the credit exposure on its off-balance sheet derivatives positions.

\section{Supermargining in OTC derivatives markets raises stability concerns.}

Supermargining refers to the practice whereby one party can impose higher collateral requirements if the other counterparty is downgraded, especially to below investment grade status. Waiting to collect additional collateral until the counterparty's creditworthiness has deteriorated, rather than collecting collateral when the position is first undertaken, can create procyclical effects especially in the face of widespread downgrades as counterparties scramble to post additional collateral.

\section{The failure of Lehman Brothers Holding Co. and problems at AIG provide an} example of the role of super-margining practices in a crisis. Lehman's collapse was preceded by months of rising credit spreads in the credit default swap market and on its corporate bonds as well as commensurate requirements by counterparties for higher rates of collateral on Lehman's derivatives transactions. That encumbered additional capital and

\footnotetext{
${ }^{12}$ The term derivatives exposure is usually measured at the replacement value of the contract or contracts. This can be thought of as the present expected value of the contracts plus any additional costs of acquiring those positions in the market, e.g., paying commissions and half the bid/ask spread.

${ }^{13}$ The Master Trading Agreement (MTA) and the CSA are standard documents prepared and copyrighted by the ISDA.
} 
liquid assets at a time when the firm was already short of capital and struggling to obtain and sustain its funding. Likewise, the downgrading of AIG forced it to begin posting collateral and brought it to the brink of collapse.

\section{Another area of concern in OTC derivatives markets is the practice of} rehypothecating collateral. Rehypothecation is a practice by which the recipient of collateral posted to secure or serve as a performance bond on a derivative or similar obligation is permitted to use that collateral as part of its own capital structure. ${ }^{14}$ The reuse by a recipient can take the form of lending the collateral, selling it in a repurchase agreement transaction for a cash loan or posting it as collateral to secure the recipients' other derivatives obligations. For example, a hedge fund, as a derivatives counterparty, may post collateral to its prime broker, and the prime broker may then use this collateral to secure its transactions as though the collateral were its own asset.

\section{At the time of its failure, Lehman had rehypothecated an estimated} US\$427 billion of its counterparties' and prime brokerage clients' assets. Counterparties as remote as Philippine banks found themselves suddenly without the hedge or investment position created by their derivatives and unable to recover liquid assets posted as collateral. Hedge funds using Lehman's prime brokerage services out of its London subsidiary discovered that Lehman had rehypothecated $\$ 22$ billion of $\$ 40$ billion of securities received as collateral. ${ }^{15}$

\section{Credit risk management in OTC derivatives markets is inherently more difficult} than in traditional lending. If a bank lends US $\$ 100$ million dollars today, it will most likely face US\$100 million in credit exposure in a month (pre-payment not withstanding). If it has a US $\$ 100$ million claim on a counterparty through a derivatives transaction (i.e., the derivatives position is in the money by US $\$ 100$ million), then the amount of the claim might be 50 percent greater or less a month later (depending on the volatility of the referenced item and the structure of the contract). The amount of counterparty credit risk is thus immediately impacted by market risk.

\section{Trading liquidity}

\section{A key feature of derivatives markets that facilitates risk management is}

liquidity. Liquidity is the ability to trade continuously and execute large transactions without

\footnotetext{
${ }^{14}$ The concern is greater in the case of the rehypothecation of initial margins, since this does represent a credit exposure to the receiving party. Transfer of variation margin, which reflects market value gain/losses between the two parties is a lesser concern since the party's net position is (by definition) under water.

${ }^{15}$ See Citi's “Are the Brokers Broken?” September 5, 2008, and hedge fund figure from Lehman's bankruptcy manager PwC, Press Release September 21, 2008 and numerous related news services reporting the amounts.
} 
impacting market prices. Under normal market conditions, an increase in price volatility can be expected to lead to an increase in trading volume. However when the market trading process itself becomes volatile or is disrupted, whether due to counterparty credit risk (especially amongst dealers), operational failures, or even extreme market price risk, then trading volume and market liquidity can suffer and result in economic costs or instability including:

- Impaired capability for risk management activities - such as entering a hedge or adjusting the size of a hedge (a critical step in dynamic hedging), or merely trading out of a losing position.

- $\quad$ Loss of price discovery in the marketplace and thereby of benchmarks for pricing other related financial instruments.

\section{Several segments of the OTC derivatives markets failed to maintain adequate} liquidity during the crisis. The lack of reporting requirements and limitations on privately collected data means that accurate data on trading volume is limited and hard to obtain. Nonetheless, what data is available does suggest a sharp drop in trading activity (see Table 6, Figures 3 and 4).

Table 6. Trading Activity

\begin{tabular}{lrr}
\hline & \multicolumn{2}{c}{ Percentage Increase in Trading } \\
\cline { 2 - 3 } & $\begin{array}{c}\text { June 2006 - } \\
\text { June 2008 }\end{array}$ & June 2008 - December \\
\hline IRS single currency & 75.5 & -13.0 \\
Less than 1 year & 71.9 & 2.0 \\
1 to 5 years & 49.3 & -16.1 \\
More than 5 years & 118.7 & -25.9 \\
Commodity & 111.6 & -72.6 \\
Forward+swap & 247.1 & -74.0 \\
Option & 32.8 & -70.6 \\
\hline Source: BIS data, author's calculations. & &
\end{tabular}

Figure 3. Trading Volume in Credit Derivatives Markets

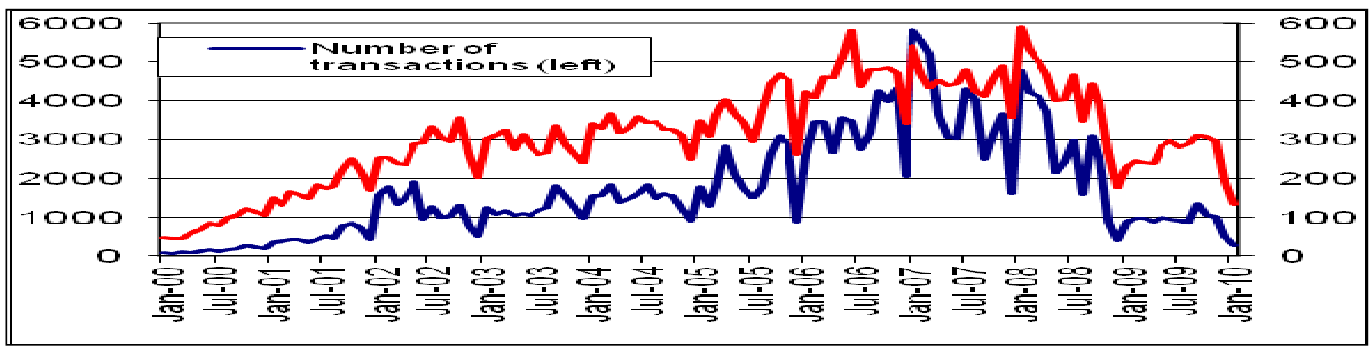


Figure 4. Liquidity in OTC Derivatives Markets: Bid/Ask Spreads in CDS

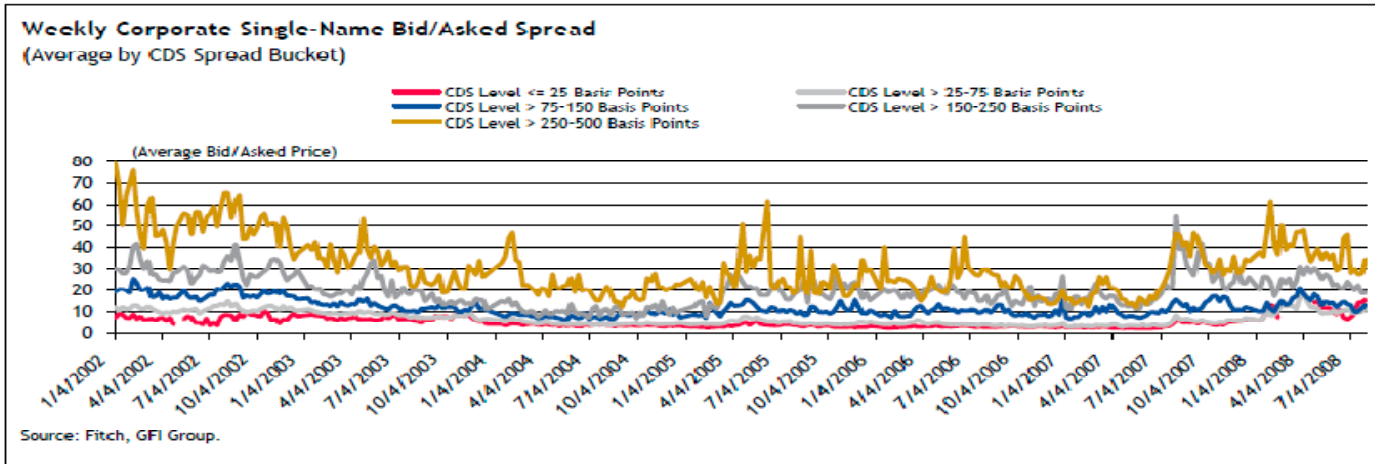

\section{Price discovery and market conduct}

\section{As with all financial markets, the price discovery process is one of the most} important economic functions of derivatives markets. Without price discovery, investors cannot mark-to-market portfolios or positions with accuracy in order to produce accurate financial statements or to determine collateral needs. Price discovery relies on liquid markets to process new, relevant market information quickly so that it is reflected in current market prices. The price discovery process in certain OTC derivatives markets broke down during the crisis. For example:

- Interest rate swaps (IRS) faced price distortions - at times trading at a negative spread to Treasury yields. Other pricing distortions in the IRS market arose from their use as a credit contract instead of pricing interest rate risk - i.e. the use of IRS, in conjunction with hedging out the related interest rate risk in order to obtain an exposure on the IRS's credit spread over Treasury securities of similar maturity.

- $\quad$ There was no price discovery in certain credit derivatives markets as certain indices completely stopped trading. In other markets, the prices or spreads discovered in the markets sometimes reflected counterparty risk and not just the creditworthiness of the referenced name or index.

- In September and October of 2008, disruptions in the valuation between one- and three-month LIBOR rates skewed pricing of OTC derivatives contracts on interest rates and exchange rates. 


\section{There have been concerns about market misconduct in the OTC derivatives} markets, and especially in regards to credit derivatives. These markets lack the transparency and oversight characterized by the exchange-traded securities and derivatives markets. ${ }^{16}$ Moreover, banks, which often have non-public information about their clients, are active in credit derivatives markets, both as dealers and in proprietary trading. In contrast to the prohibition against banks holding equities or corporate debt securities on their balance sheets, they are allowed to operate as major derivatives dealers in OTC equity, total return swaps, and credit derivatives markets. ${ }^{17}$

\section{Market conduct in OTC markets has become a concern to regulators. The} Securities and Exchange Commission (SEC), Department of Justice and New York State Attorney General have launched numerous investigations into such matters. The Chairman of the SEC testified to the U.S. Senate Banking Committee in 2008 on the potential for manipulation in CDS markets which he described as "completely lacking in transparency and completely unregulated." There are some notable cases, such as Harrah and HCA, of unusual trading activity in OTC market's prior to the announcement of a heavily debt financed merger or buy-out. A study using CDS spread data by Archarya and Johnson (2007) found evidence of trading on non-public information in the CDS market prior to the public announcements.

28. These types of problems are hard to police in OTC markets. Insider trading is regularly monitored on securities exchanges by authorities who can use automated surveillance systems to comb through market trading information for unusual activity prior to a public announcement or publicly announced event. Such enforcement is difficult in the context of an OTC market, and while both the Bond Market Association and the International Swaps and Derivatives Association have issued guidelines for dealing with conflicts of interest, these organizations are trade associations and so have no authority over their members. Pursuant to the Securities Exchange Act of 1934, the SEC has anti-fraud authority over credit swaps linked to securities (i.e., corporate bonds), but the scope of that authority is being contested in court. ${ }^{18}$

\footnotetext{
${ }^{16}$ In recent years though, the growing use of DTCC's Warehouse Trust Company, trade data repository has greatly improved the reporting and record keeping of such OTC credit derivative transactions.

${ }^{17}$ PIMCO published a White Paper on this problem in October 2002, which stated, "Credit default markets are the mechanism within which friendly commercial bankers and others privy to inside information can profit by betraying and destroying their clients through the use of inside information."

${ }^{18}$ See the Wall Street Journal and New York Times (March 31, 2010) reporting on New York federal court taking up the challenge to SEC authority in a case involving Deutsche Bank and Millennium Capital hedge fund.
} 


\section{Regulatory Proposals}

29. The U.S. Congress passed a set of comprehensive reforms making fundamental changes in the regulation of derivatives markets in July of 2010. The effort began with the Treasury Department putting forth a 'white paper' in June of 2009. ${ }^{19}$ The House of Representatives passed its version of the reform proposals, H.R. 4173, on December 13, 2009, and the Senate passed its version on May 20, 2010. A conference was held and it produced a report on June 29, H. Rept. 111-517, that was in turn passed by the House and the Senate. For the purposes of the following discussion, the term reform or the Act refers to the Conference Report version of the legislation.

\section{Registration}

\section{Registration plays a key role in financial market regulation and supervision.}

Registration requirements can be applied to firms and individuals participating in financial markets and it can refer to the instruments, such as securities, that are traded in financial markets. It provides supervisors with a census of market participants, incorporates minimum standards for capital and business conduct, and both allow for background checks of key personnel. In securities markets, registration both creates a record of public securities issuances and subjects those securities to the relevant regulations such as the standards for disclosure of offering prospectus and regular financial statements.

\section{The need for registration in OTC derivatives markets is comparable, though not} identical, to that in securities markets. In regards to exchange-traded derivatives, the firms and key individuals - including exchanges, brokers ${ }^{20}$ and trading advisors - were already chartered and licensed in a manner similar to other areas of the U.S. financial system. Certain exchange-traded derivatives contracts, such as futures and options on futures are not issued but created in the trading process. These contracts are not registered, per se, but they are subject to regulatory approval. Until the 2000 Commodity Futures Modernization Act (CFMA), listed futures contracts were subject to pre-approval by the CFTC. Since that time futures exchanges can list new contracts through a self-certification process (i.e., without authorization) although the regulatory authorities may subsequently object if the contracts are deemed to be inconsistent with regulatory standards. Securities options also are not registered or approved, but must meet exchange listing standards requirements, which are approved by the SEC.

\footnotetext{
${ }^{19}$ U.S. Treasury Department, A New Foundation: Rebuilding Financial Supervision and Regulation. June 17, 2009.

${ }^{20}$ The legal term for brokers in the futures markets is a Futures Commission Merchant, but the more familiar term broker will be used in this note. Also note that exchange-traded options on securities and narrow-based security indices were already regulated as securities.
} 


\section{The reforms include three changes in the area of registration that are designed} to address some of the problems that arose during the crisis. First, OTC derivatives dealers and a class of market participants labeled major swap participants (MSP) ${ }^{21}$ are required to register with the CFTC or the SEC depending upon whether they trade in "swaps" or "security-based swaps." 22 Major swap participants (MSP) would be required to register irrespective of whether they are otherwise registered as a financial firm. For example, a hedge fund would be classified as an MSP but a farmer hedging his crop would not and neither would a non-financial firm hedging its currency risk, interest rate risk or commodity price risk. In addition the "Lincoln Amendment," also known as the push-out provision will prohibit these entities from receiving federal assistance, FDIC deposit insurance, and access to the Fed discount window. While there are exemptions for trading in interest rate and foreign exchange swaps, trading in other derivatives products must be moved out of the bank and into an affiliate.

\section{In addition, the Act requires registration for any firm that holds collateral or} margin for a derivatives transaction cleared through a clearing house or clearing agency. This does apply to bilaterally cleared swap participants. It requires registration for swap data repositories that will receive the transaction and price reports also required in the Act. While exchanges are currently registered as 'contract markets' the Act will also require that 'swap execution facilities' be registered if it is to trade swaps designed for clearing and exchange trading. In addition, derivatives clearing organizations and clearing agencies that cleared derivatives subject to clearing requirements, must register with the respective agency.

\section{A second important change applies to the implicit registration of certain classes}

of derivatives instruments. Although there is no blanket registration requirement of contracts per se, such as applies to publicly traded securities, the new regulatory reforms will authorize the CFTC and SEC to determine which instruments should be subject to multilateral clearing and (allowing for some exemptions) required to trade on an exchange (a 'contract market') or swap execution facility. The proposed legislation also requires that any registered entity, i.e., exchange, swap facility or clearing organization, report any new contract for trading or clearing to the relevant Commission. ${ }^{23}$ It requires registered clearing organizations and agencies to provide a list of contracts eligible for clearing. Together this would create a 'positive' list of instruments that have been reviewed and accepted as suitable for multilateral clearing and trading. In addition, the Act will subject certain security-based

\footnotetext{
${ }^{21}$ Major swap participants are defined as firms with substantial positions and that are highly leveraged.

${ }^{22}$ The legislation defines as swap to include the usual array of OTC derivatives contracts such as forward, option, swap and the more exotic second- and third-generation derivatives. It includes foreign-exchange based forwards and swaps. It exempts certain contracts for delivery in the future is they are settled by physical delivery.

${ }^{23}$ See Section 125 of H.R. 3795.
} 
swaps transactions to the registration process of the 1933 Securities Act. This change is designed to improve transparency and to protect less sophisticated investors. ${ }^{24}$

35. A third change is the requirement for managers of private pools of capital, such as hedge funds, to register as investment advisers. Investment advisors will be required to register, keep records, and report on their activities if assets under management exceed US \$100 million. This will cover a large share of market participants who have previously not been required to register and comply with minimum standards, record-keeping requirements, or reporting obligations like most other financial firms in the U.S. financial system. While the requirement for "major swap participants" to register is likely to include most relevant hedge funds, the investment advisors registration will help close any loophole remaining in the interpretation and compliance with the law.

\section{The registration of hedge fund advisors and other private pools of capital is an} important step and reflects the significance of their role in the economy. Some hedge funds have been major participants in derivatives markets. They functioned as counterparties to dealers in a large share of transactions in credit derivatives and other OTC derivatives. Their willingness to take on greater risks made them desirable counterparties and added liquidity to the markets. Their business models often involve active trading to manage risk, realize gains and reposition exposures in response to new information or opportunities. This generated liquidity, as well as commissions, for OTC derivatives dealers. Their trading activities amounted to a substantial portion of OTC derivatives markets. The loss of such liquidity and counterparties when the financial crisis crippled many of the highly leveraged funds had an immediate adverse impact on the dealers and these markets.

\section{Reporting requirements}

37. The primary regulatory remedy for the lack of transparency in OTC derivatives markets is to require more complete reporting of derivatives trading and positions. At present, reporting requirements for exchange traded and OTC derivatives differ sharply. Each futures exchange collects information on every futures and options on futures trade that occurs on the exchange. In addition, futures exchanges collect information on OTC derivatives that clear through their clearing house and on those that are converted to futures contracts through an "exchange futures for swaps" facility. The futures exchanges provide real-time price and volume data throughout the trading day, and offer aggregated information on prices, volume, and open interest and other statistics as of the close of the trading day. This is in sharp contrast to the reporting requirements for OTC transactions.

\footnotetext{
${ }^{24}$ It also prohibits state insurance authorities from regulating a credit derivative or other security-based swap as an insurance contract.
} 
38. The Act will result in every OTC derivatives transaction being reported to a registered repository or the relevant regulatory agency. Derivatives cleared through a clearing house will be reported by the clearing house, and those not multilaterally cleared will be required to report directly to a repository or to the relevant regulatory authority. The pricing data will be reported in real time and the other transactional data will be aggregated and released to the public.

39. The Act will require daily "large trader reporting" by swap dealers and major swap participants, in addition to existing such reporting requirements. A large trader reporting system allows the exchanges, clearing houses and regulators to detect the build up of large positions that might pose threats to individual firms, the markets or the overall financial system. A version of the data, although previously limited to exchange traded activity, known as the Commitment of Traders report, is released to the public weekly. This can be used also to detect and deter manipulation schemes, and to identify potentially destabilizing exposures. This information can be critical in avoiding the surveillance failures that contributed to crises at certain clearing houses in past decades. ${ }^{25}$

\section{Clearing and Multilateral Trading Requirements}

40. Up until now, OTC derivatives markets have largely cleared bilaterally where counterparties have relied on credit assessments, collateral and close-out netting agreements to manage current and potential counterparty credit exposures. One major exception is LCH Clearnet Group's SwapClear. Established in 1998, it currently serves 25 clearing members in the interdealer market and claims to clear 93 percent of trades it deems sufficiently standards or 'eligible' for its clearing process. Credit risk is managed by careful evaluation of clearing members, the use of margin to collateralize the transactions, and an established default management system.

\section{Another exception is the facility offered by many clearing houses for futures} exchanges to accommodate 'exchange futures for swaps' transactions that allow OTC trades to be converted into futures trades in the clearing house. In the wake of Enron's failure, NYMEX created ClearPort to clear OTC trades in energy derivatives and the electronic Intercontinental Exchange (ICE and precursor to ICE Trust) also offered these services. In addition, the Continuous Linked Settlement (CLS) of foreign exchange transactions founded in the late 1990s has reduced the risk of Herstatt type counterparty failures in interdealer foreign exchange derivatives settlements. It is not a clearing house, however, and functions like a escrow account in finalizing payments.

\footnotetext{
${ }^{25}$ See Global Financial Stability Report (April 2010), Chapter 3, Box 3.5 on History of Central Counterparty Failures or Near-Failures.
} 
42. More recently there have been important innovations in the clearing of OTC traded credit derivatives. One is the Depository Trust and Clearing Corporation (DTCC) Deriv/Serv that confirms a large range of OTC derivatives trades and is linked to its trade data repository, the Warehouse Trust Company. This contributes to market efficiency and stability in several ways. The confirmation of trades reduces operational uncertainty arising from the failure to promptly determine exact exposures on a day-to-day basis. It also stores a 'gold' copy of the derivatives contract, which is sometimes subject to amendment, and thus reduces the uncertainty of contract terms and reduces the likelihood that disputes must be resolved through costly court action. Moreover, the aggregate data provided by DTCC provide market participants with the amount of outstanding contracts on the various corporate or sovereign names and credit indices. The second exception is LCH Clearnet Group's SwapClear, a clearing house of OTC interest rate swaps. According to LCH, it currently services about 20 percent of total global OTC interest rate derivatives markets, 50 percent of inter-dealer trades in that market and some 93 percent of eligible ${ }^{26}$ trades. Credit $^{-}$ risk is managed by careful evaluation of clearing members, the use of margin to collateralize the transactions, and an established default management system.

\section{Other important innovations in the clearing of OTC credit derivatives comes} from the establishment of several new clearing houses. One is ICE Trust, a New York State trust company that will fall under the supervision of the Federal Reserve Bank of New York. Another is CME Group that is supervised by the CFTC. Two European entities, NYSE Euronext and LCH.Clearnet received regulatory approval to offer such clearing services to approved U.S. traders. NYSE Euronext, Eurex Clear and ICE Clear will offer credit derivatives and other derivatives clearing services in Europe. ${ }^{27}$

\section{The Act includes reforms for the robust regulation of the multilateral clearing} process and the multilateral trading of derivatives. While exchange-traded derivatives are currently cleared through regulated clearing houses, the proposal will generally require all derivatives transactions to be cleared by a regulated clearing house unless they meet certain exemptions. It is estimated that between 75-80 percent of OTC derivatives transactions are sufficiently standard that they can be multilaterally cleared. ${ }^{28}$ The CFTC and SEC are authorized to review all swap contracts and determine which are appropriate for multilateral clearing through a clearing house. The clearing house is not required to accept all contracts for clearing, but is required to justify its decisions. Once a contract is deemed appropriate for clearing and accepted by a clearing house, it is required to be trading by an exchange or a registered swap execution facility.

\footnotetext{
${ }^{26} \mathrm{LCH}$ accommodates customization along several dimensions, and this defines what is an eligible contract, but certain levels of complexity are rejected as too economically costly for multilateral clearing.

${ }^{27}$ See the April 2010 issue of GFSR, Chapter 3, for a longer discussion of these new clearing entities.

${ }^{28}$ CFTC Chair Gary Gensler at the annual FIA industry conference, March 2010.
} 
45. There would be certain exemptions from these clearing requirements. Certain OTC derivatives trades would be exempt from the clearing requirement if the appropriate regulator determines that they should not be subject to the clearing requirement. They would also be exempt if no existing DCO would accept them for clearing. Another exemption would apply if one party is an end-user of derivatives and not a dealer or a 'major swap participant.'

\section{Capital and collateral requirements}

46. Capital requirements are imposed on financial institutions with the objective of governing their risk taking and maintaining their solvency in the event of unexpected losses. ${ }^{29}$ The financial crisis revealed that the major financial firms making up the network of OTC derivatives dealers did not have sufficient capital to withstand losses from their derivatives and cash market trading activities. The Act requires higher capital requirements for risk exposures arising from OTC derivatives trading, especially for swaps that are not cleared by a registered derivatives clearing organization. The Act contains nondiscriminatory provisions that prohibit clearing organizations associated with exchanges or Swap Execution Facilities (SEF) from rejecting contracts traded in other venues. ${ }^{30}$

\section{The regulatory reforms seek to enhance the resiliency of the financial system by} shifting a large share of OTC derivatives trading to clearing houses and exchanges. Higher capital requirements would result in the employment of lower overall leverage (measured as exposure of market risk given the amount of capital) by major financial firms and reduced externalities from risk-taking by major financial firms. It would create further incentives to move towards multilateral clearing and trading of derivatives.

\section{The Act will raise standards for the use of collateral from existing business} practices in managing counterparty risk in OTC derivatives markets that have proven to be faulty. In order to help prevent another situation where there is too little collateral until it is too late, the reforms authorize the prudential regulators, CFTC and SEC, to directly set collateral (margin) requirements for all non-cleared derivatives transactions- - whether traded on exchanges or OTC and to oversee the collateral requirements set by registered derivatives clearing organizations. There are exemptions for OTC trades with certain end-users that are using OTC derivatives only to hedge existing commercial risks.

\footnotetext{
${ }^{29}$ The risks of expected losses are supposed to be handled through credit spreads on loans and collateralization and diversification of exposures.

${ }^{30}$ This mirrors similar prohibitions covering securities clearing and is intended to avoid the exercise of monopolistic power by vertically integrated trading and clearing organizations such as traditional futures exchanges.
} 
49. The risk to investors' own collateral, brought to light by the failure of Lehman Brothers, is another problem addressed by the reforms. The Act will also require the segregation of collateral or margin funds for derivatives cleared through clearing houses, and for bilaterally cleared trades it will give counterparties the right to have initial margin funds held in a segregated account by a third party. This will curtail the comingling of funds and the rehypothecation of collateral for all derivatives transactions that are required to be cleared, and it will reduce the incidence of the problem for those that remain in the OTC market sphere. By protecting investors' collateral it will reduce uncertainty about counterparty risk, especially during times of stress and heightened market fear, and will thus put these markets on a more stable footing. Market participants that continue to trade in OTC markets can still elect to allow their initial margin funds to be comingled.

\section{Market conduct provisions for OTC derivatives markets}

\section{OTC derivatives, especially when they are customized and lack established} market prices, are susceptible to misuse and even fraud. When valuation depends upon complex pricing models it often leaves the end-user at a disadvantage in comparison to the more sophisticated dealer with whom they are trading. Moreover, derivatives contract structures can be complex, possibly overwhelming the end-users' capacity to assess market risks when undertaking such transactions. An important example in the transmission of the financial crisis to emerging markets was the trading of a class of exotic derivatives known as knock-in-knock-out options (KIKOs) or target redemption notes (TARNs). ${ }^{31}$

\section{The regulatory reforms extend to OTC derivatives markets the anti-fraud and} anti-manipulation measures that have long existed for exchange-traded derivatives markets. ${ }^{32}$ The anti-manipulation authority would be substantially strengthened by the position reporting requirements mentioned above, which will increase the ability of authorities to monitor the marketplace, and position limits that will empower authorities to require a market participant to reduce a large position. While the final version of the legislation did not contain requirements for derivatives dealers to exercise fiduciary responsibilities for their customers, it did establish certain business conduct rules. When trading with non-dealers and non-MSP, they are required to disclose to material risks, conflicts of interest, and a daily mark to market valuation. An even higher standard is set for trading with special entities such as pension funds and municipal governments.

\section{The reforms will give supervisory agencies greater enforcement authority,} especially in the area of insider trading. The Act grants the CFTC more powers over

\footnotetext{
${ }^{31}$ Dodd (2009a) and (2009b).

${ }^{32}$ After passage of the CFMA, the SEC retained anti-fraud authority over some securities-based swap. The Food, Conservation, and Energy Act of 2008 (known as the Farm Bill of 2008) restored to the CFTC anti-fraud authority over OTC transactions in commodities such as energy and metals, but not for financial products.
} 
information released by government agencies that might affect market prices. It prohibits trading when it is known that the counterparty is engaging in fraud. It supports the trading rules of regulated exchanges and SEF by prohibiting the violation of their trading rules, such as making quotes with the intent of cancelling prior to execution. The Act authorizes the CFTC and SEC to report on certain types of derivatives transactions that the agencies deem to threaten market stability. The statute does not include the authority to outlaw the trading in some contracts or create a negative list. Such a regulatory practice already exists to a small degree for exchange traded futures and options on agricultural commodities, ${ }^{33}$ and it was once broadly used in the past. In other countries, a negative list, or alternatively a "positive" list of permissible transactions, is used to define the range of derivatives trading that is suitable to certain investors or that is within the risk management capabilities of the major financial institutions. ${ }^{34}$

\section{ASSESSMENT OF REgUlATORY REFORMS}

53. The regulatory reforms presented by the Treasury proposal and passed into legislation by the House of Representatives and the Senate makes major improvements to the regulatory framework for derivatives. The changes address to a very large extent the problems in OTC derivatives markets that were revealed in the financial crisis. They would improve transparency through blanket requirements to report derivatives transactions, and would also substantially strengthen the ability of authorities to monitor derivatives market positions and trading. The reforms would reduce leverage in the financial system by authorizing the various prudential regulators, CFTC and SEC to increase capital requirements for OTC derivatives trading and to establish minimum collateral requirements for all noncleared derivatives transactions. Regulated clearing houses would set collateral requirements derivatives for those required to be cleared on multilateral basis. As a result, counterparty risk would be substantially reduced and what remains would be better managed.

\section{The proposed reforms would make major improvements to market trading} liquidity and the price discovery process. The efforts to move trading onto exchanges, require market wide real-time transactional reporting requirements as well as to better manage counterparty risk through collateral, capital and clearing houses, will make the markets more transparent and market trading volume more resilient to economic disruptions.

\section{What is still uncertain is the extent to which OTC trades will be cleared through clearing houses and transactions will move to exchanges or similar multilateral trading}

\footnotetext{
${ }^{33}$ The Commodity Exchange Act, as amended in 1974, prohibits derivatives on onions and the CFMA of 2000 prohibits trading OTC derivatives on certain enumerated (i.e., listed in the Act) agricultural commodities.

${ }^{34}$ For example, Chile prohibited the trading in foreign exchange options until a dealer could prove that it had sufficient risk management capabilities, such as value at risk models, to take on the risks inherent in such market making.
} 
venues. While recent developments in the credit derivatives markets indicate that such a movement towards multilateral clearing and trading of standardized contracts is feasible, an important role will be played by the regulatory agencies to determine which contracts much be cleared through a clearing house and thus which must be exchange traded. This will also depend on the breadth of the agencies' interpretation of the exemptions for certain end-users and guidelines for determining appropriate degrees of standardization for multilateral clearing and trading.

56. One measure that has not been included in the proposed reforms is to require dealers to support market liquidity with actions such as maintaining binding bid and ask quotes in the market. To the extent that OTC derivatives trading migrates to exchanges, this is not a major deficiency but if trading remains in OTC markets this would leave the market structures with the same lack of dependable trading liquidity. ${ }^{35}$

57. Finally, the reversal of the 2000 deregulation of OTC derivatives marks a major improvement in regulatory approach, and it closes an important gap in the regulatory framework.

\footnotetext{
${ }^{35}$ Binding market making requirements are not unusual. The New York Federal Reserve Bank requires that primary dealers in the U.S. Treasury securities markets maintain binding quotes in Treasury securities through the trading day. OTC markets in equity shares have designated dealers that are required to similarly maintain binding bid and offer quotes throughout the trading day.
} 


\section{APPEndix I: Primer on Derivatives Markets ${ }^{36}$}

58. A derivative is a transaction that is designed to create price exposure, and thereby transfer risk, by having its value determined-or derived-from the value of an underlying commodity, security, index, rate or event. Unlike stocks, bonds and bank loans, derivatives generally do not involve the transfer of a title or principal, and thus can be thought of as creating pure price exposure, by linking their value to a notional amount or principal of the underlying item.

\section{A forward contract is the simplest and perhaps oldest form of a derivative} contract. This term is used in OTC financial instrument markets to mean the obligation to buy or borrow (sell or lend) a specified quantity of a specified item at a specified price or rate at a specified time in the future. A forward contract on foreign currency might involve party A buying (and party B selling) 1,000,000 Euros for U.S. dollars at US\$1.3605 on December 1, 2010. A forward rate agreement on interest rates might involve party A borrowing (party B lending) US $\$ 1,000,000$ for three months (91 days) at a 2.85 percent annual rate beginning December 1, 2010. Alternatively, there is a forward markets for U.S. Treasury securities, known as the "when-issued" market, in which the forward specifies delivery following the auction of new securities notes and bonds. Under the Commodity Exchange Act, a forward contract is a cash transaction common in many industries, including commodity merchandising, in which a commercial buyer and seller agree upon delivery of a specified quality and quantity of goods at a specified future date. Terms may be more "personalized" than is the case with standardized exchange traded futures contracts (i.e., delivery time and amount are as determined between seller and buyer). A price may be agreed upon in advance, or there may be agreement that the price will be determined at the time of delivery.

\section{Exchange traded futures contracts, are highly standardized and cleared through} clearing houses. The futures contracts traded are so standardized that they are fungible or fully substitutable one for another on the exchange listing the contract. This enhances liquidity and facilitates trading by allowing a purchase and sale to fully offset one another.

\section{In contrast to OTC traded forwards, the trading in exchange "pits" or on their} electronic order matching platforms is public and multilateral. Trading in traditional pits involves the very public statement of bid and offer prices known as "open outcry." Open outcry is not only public, but also multilateral because all market participants can hit a bid, lift an offer, or raise or lower the quote. In this environment, all market participants can observe the bid, offer and execution prices and thereby know whether the prices they are agreeing to are the best prevailing market prices.

\footnotetext{
${ }^{36}$ See Financial Policy Forum, Primer on Derivatives Instruments at www.financialpolicy.org
} 


\section{Clearing houses are used to clear all exchange-traded futures and options}

contracts. Trades from the exchange are reported to the clearing house, and the contracts are written anew between traders and the clearing house, or novated, so that the clearing house becomes the counterparty to every contract. In a novation, two parties terminate the contract between them, and one of the parties enters into a new contract on identical terms with a new counterparty. In this manner, the clearing house assumes the credit risk of every contract traded on the exchange. While the clearing house directly 'faces off' with only clearing members, in doing so it provides a high quality credit guarantee on the financial performance of the derivatives contracts that it clears. Instead of having to perform a credit evaluation of every actual and potential trading partner, the futures trader has only to evaluate the creditworthiness of the clearing house and the clearing member handling the trader's futures brokerage account, and in the case of U.S. futures exchanges, the clearing houses are all considered highly creditworthy and have never failed to pay funds due its clearing members.

63. Whereas a futures contract entails an obligation on both counterparties to transact at a specific price at a future date, an option contract gives the buyer (seller) the right to buy (sell) the underlying item at a specific price at a specific time period in the future. In the case of a call option, the owner has the right to buy the underlying item at a specified price - known as the strike or exercise price - at or before a specified time in the future. In the case of a put option, the option holder has the right to sell the underlying item at the strike or exercise price at a specified time in the future. Whereas the holder of the option has the right to exercise the option in order to buy or sell at the more favorable strike price, the writer or seller of the option (known as the short options position) has the obligation to fulfill the contract if it is exercised by the option buyer. The writer of an option is thus exposed to potentially unlimited losses. The write of a call option is exposed to losses from the market price rising above the strike price, and the writer of a put option is exposed to losses if the price of the underlying item were to fall below that of the exercise price.

64. There are several basic styles or structures of options. An American style option can be exercised at any point during a specified period which is usually the life of the contract, while European style options can be exercised only on the expiration date. An Asian option is path dependent such as ones that pay the difference between the average price and the strike or the most extreme price and the strike over the exercise period. Barrier options contain knock-out or knock-in provisions that void the contract if a price hits the knock-out point or must hit the knock-in price before the option is exercisable. Exotic options can in many forms but they are known for their complexity and difficulty to price.

65. The value or price paid to buy an option is known as the premium. It is determined by the length of time before the option expires, the volatility of the underlying item, the current market price, the strike price and the market rate of interest. Although the specifics of this relationship are more precisely expressed in closed form equations such as the Black-Scholes formula or the Binary or lattice models, the basic economic reasoning is the same. Like an 
insurance policy, the price paid for the option is called a premium, however the exercise value is not an indemnity and it is not dependent upon there being a specific loss or damage.

66. The swap contract is a more recent innovation in contract design. The first currency swap contract, between the World Bank and IBM, dates to August of 1981. The basic idea in a swap contract is that the counterparties agree to swap two different types of payments. Each payment is calculated by applying some interest rate, index, exchange rate, or the price of some underlying commodity or asset to a notional principal. The principal is considered notional because the swap generally does not involve a transfer or exchange of principal (except for foreign exchange and some foreign currency swaps). Payments are scheduled at regular intervals throughout the tenor or lifetime of the swap. When the payments are to be made in the same currency, then only the net amount of the payments are made.

67. There are several basic types of swaps. A "vanilla" interest rate swap is structured so that one series of payments is based on a fixed interest rate and the other series is based on a floating or variable interest rate. A foreign exchange swap is structured so that the opening payment involves buying the foreign currency at a specified exchange rate, and the closing payment involves selling the currency at a specified exchange rate. Thus it is akin to a spot transaction combined with a forward contract. A foreign currency swap is structured so that one series of payments is based on one currency's interest rate and the other series of payments is based on another currency's interest rate. An equity swap has one series of payments based on a long (or short) position in a stock or stock index, and the other series is based on an interest rate or a different equity position.

68. Structured notes, also known as securities, contain features of both conventional debt securities and derivatives. The term "note" usually refers to a public or private credit instrument like a bond, and may have a maturity that ranges between two and ten years. The term "structured" refers to an attached derivative or other contingent payment schedule. Structured notes are part of a broader class of financial instruments that contain features of both securities and derivatives. Examples of these instruments include familiar instruments such as callable bonds, convertible bonds and convertible preferred stock.

\section{There are two basic economic purposes for derivatives markets: risk}

management and price discovery. Risk management, such as hedging, includes the transfer of risk from those who are less willing and able to bear it towards those who are more willing and able. Derivatives trading is not always a mere transference of risk, and it sometimes serves to eliminate risk. Consider the following two straightforward examples. A farm hedging its crop by selling short (using a forward, futures, swap or options strategy) to a food processor who is buying long, and a bank using a vanilla interest rate swap (receiving the floating rate and paying the fixed rate in order to hedge the cost of its short term funding liabilities) contract with a pension fund that is trying to increase the maturity of its fixed 
income portfolio. Eliminating one type of risk, in the above case market risk, creates another type, credit risk.

70. More efficient risk management promotes investment by allowing investors to take on the risks they want and avoid the ones they do not. For example, traditional banking activity focuses on the efficiency of credit evaluations in underwriting loans. Banks that are good at this activity might seek to expand their lending activity, but for the interest rate risk arising from the duration mismatch between their liabilities and loans. Hedging that risk through interest rate linked derivatives would allow the bank to concentrate on its strong suit and expand its lending activities without exposing it to greater interest rate risk.

\section{One feature of derivatives markets that improves the efficiency of risk} management is the greater liquidity in trading in and out of positions. Liquidity helps to lower the cost of conducting a derivatives transaction and it also facilitates the adjustment of a hedge or risk management position in response to changing circumstances. For example, if the magnitude of the pre-existing risk - such as a larger than expected crop or an unexpected drop in short-term funding needs - were to change, then the size of the hedge would need to change. An illiquid market would raise the cost of hedging and possibly thwart or make prohibitively expensive any subsequent adjustment to a hedging position. Although market trading liquidity is not necessary, it does provide significant potential hedging benefits.

\section{A second basic economic purpose of derivatives market is price discovery. By} dent of their lower trading costs, greater liquidity or the standardization of the reference entity, derivatives markets often serve as the primary markets for determining the prices of commodities and financial assets and the market value of certain risks and events.

\section{The importance of price discovery is so profound that it was written into U.S.}

law. It is explicitly stated as one of the motivating reasons for regulating derivatives markets. Section 3 of the Commodity Exchange Act, entitled "The Necessity of Regulation," stated, until being amended as part of deregulation in 2000, the following.

“'Futures' are affected with a national public interest. Such futures transactions are carried on in large volume by the public generally and by persons engaged in the business of buying and selling commodities and the products and byproducts thereof in interstate commerce. The prices involved in such transactions are generally quoted and disseminated throughout the United States and foreign countries as a basis for determining the prices to the producer and consumer of commodities and the products and by-products thereof and to facilitate the movements thereof in interstate commerce. Such transactions are utilized by shippers, dealers, millers, and others engaged in handling commodities... The transactions and prices of commodities on such boards of trade are susceptible to excessive speculation and can be manipulated, controlled, cornered or squeezed, to the detriment of the producer or 
the consumer and the persons handling commodities and products and byproducts thereof in interstate commerce, rendering regulation imperative for the protection of such commerce and the national public interest therein." 


\section{REFERENCES}

Acharya, V. V., and T. C. Johnson, 2007, "Insider Trading in Credit Derivatives," Journal of Financial Economics, 84, 110-141.

Cecchetti, S. G., et al., 2009, “Central counterparties for over-the-counter derivatives.” BIS Quarterly Review (September 2009).

Chailloux, Alexandre and Simon, 2009, "The Rise and Fall of the Repo Empire.” IMF staff manuscript.

Dodd, Randall, 2009a, "Playing with fire." Finance and Development, Volume 46, Number 3. (September 2009).

Dodd, Randall, 2009b, "Exotic Derivatives Losses in Emerging Markets: Questions of Suitability, Concerns for Stability" IMF Working Paper (forthcoming).

Duffie, Darrell, 2009, How should we regulate derivatives markets? PEW Financial Reform Project.

Fitch Ratings, 2008, "Corporate CDS Market: Current Spread and Volume Trends," Fitch Ratings Credit Policy Special Report, August 8.

Garvy, George, 1944, "Rivals and Interlopers in the History of the New York Security Market.” Journal of Political Economy, Vol. 52, No. 2, pp. 128-143.

Gorton, Gary and Andrew Mattrick, 2009, “Run on Repo.” Manuscript.

ICAP, 2009, "White Paper: The Future of the OTC Markets," Published by firm and signed by COO Mark Yallop (November 10, 2009).

Singh, Manmohan and James Aitken, 2009, Deleveraging after Lehman-Evidence from Reduced Rehypothecation. IMF Working Paper WP/09/42 (Washington, DC, International Monetary Fund). 